\title{
The Dangers of Humanitarian Intervention and the Responsibility to Protect Doctrine, and a Partial Solution
}

Matthew Bellinger

Indiana University Maurer School of Law, bellingm@iu.edu

Follow this and additional works at: https://www.repository.law.indiana.edu/ijgls

Part of the Comparative and Foreign Law Commons, International Humanitarian Law Commons, and the Military, War, and Peace Commons

\section{Recommended Citation}

Bellinger, Matthew (2020) "The Dangers of Humanitarian Intervention and the Responsibility to Protect Doctrine, and a Partial Solution," Indiana Journal of Global Legal Studies: Vol. 27 : Iss. 2 , Article 8.

Available at: https://www.repository.law.indiana.edu/ijgls/vol27/iss2/8

This Note is brought to you for free and open access by the Law School Journals at Digital Repository @ Maurer Law. It has been accepted for inclusion in Indiana Journal of Global Legal Studies by an authorized editor of Digital Repository@Maurer Law. For more information, please contactrvaughan@indiana.edu.

\section{$\Psi$}

JEROME HALL LAW LIBRARY

INDIANA UNIVERSITY

Maurer School of Law
Bloomington 


\title{
Temporary Protection Status: A Yugoslavian Precedent
}

\author{
MEDINA DZUBUR*
}

History provides a lens to interpret events shaping modern society. It encapsulates perspectives from varying ethnic, religious, and gender classes. These perspectives provide key analyses regarding the intentions and movements of important actors and groups as well as providing lessons for the "advancement of peace and prosperity" in society. ${ }^{1}$ Even though historians and scholars have compiled mass amounts of information related to the timeline of war, the modern world continues to be plagued by this phenomenon. War conflicts continue to displace millions of individuals each year, forcing them out of their homes and away from their families. For this reason alone, it is important to analyze history to articulate a comprehensive understanding of why displacement events continue to occur in the modern day, ${ }^{2}$ and how the law can mitigate the consequences of mass immigration.

The end of the Cold $\mathrm{War}^{3}$ led the world to believe that many "displaced persons would soon be able to return home and ... rebuild their lives." ${ }^{4}$ However, a declaration of independence from Yugoslavia

* J.D. Candidate, 2020, Indiana University Maurer School of Law-Bloomington, IN; B.A., 2017, Michigan State University-East Lansing, MI. I would like to thank my parents, Emir and Suada Dzubur, for inspiring me to write this paper and for motivating me every day with their inspirational story. Additionally, I would like to thank my brother, Dzenis Dzubur-we support each other every day in hopes of making our parents proud.

1. Amanda Caldwell, Note, Causes, Consequences, and the International Impact of the War in the Former Yugoslavia, RUTGERS J.L. \& RELIGION, Jan. 2001, at 1 (2001).

2. Id.

3. See Rocco P. Cervoni, Note, Beating Plowshares into Swords - Reconciling the Sovereign Right to Self-Determination with Individual Human Rights Through an International Criminal Court: The Lessons of the Former Yugoslavia and Rtoanda as a Frontispiece, 12 ST. JOHN's J.L. COMMENT. 477, 482 (1997).

4. Eric Rosand, The Right to Return Under the International Law Following Mass Dislocation: The Bosnian Precedent?, 19 MICH. J. INT'L L. 1091, 1092 (1998). See generally GUY S. GOODWIN-GILL \& JANE MCADAM, THE REFUGEE IN INTERNATIONAL LAW (3d ed. 2007) (analyzing the framework of international refugee law).

Indiana Journal of Global Legal Studies Vol. 27 \#2 (Spring 2020)

(C) Indiana University Maurer School of Law 
by Croatia and Slovenia in $1991^{5}$ quickly led to a violent eruption that contradicted the notion of return. The Yugoslav Wars created a massive refugee crisis that formed a new precedent in international law. ${ }^{6}$ The term "temporary protection" first appeared in the European Union (EU) during the Yugoslavian conflict: it was originally described as a "flexible and pragmatic means of affording needed protection to large numbers of people fleeing human rights abuses and armed conflict in their country of origin, who might otherwise have overwhelmed asylum procedures." 7 Since the development of this precedent, not a single EU Member State has granted protection under this status or even engaged in discussion on its possible use. ${ }^{8}$ These discussions have failed to occur despite the Syrian refugee crisis, which has proven to be one of the largest refugee crises that Europe has ever witnessed. ${ }^{9}$

Analyzing the past use of temporary protection status to shield those facing "ethnic cleansing, massacres, mass rapes, and cultural vandalism" 10 is fundamental in understanding how this tool can be utilized to protect modern refugees, and why EU members have refused to implement this status further. In other words, should temporary protection status, considering the legal framework and the socioeconomic effects, be granted to Syrian refugees? This note argues in favor of granting temporary protection status to Syrian refugees because the status (1) offers a recourse for displaced persons that would not be covered by traditional legal protections, (2) produces quicker results, and (3) grants refugees with basic human rights not currently available in their home country.

Part I of this note describes how the ethnic tensions led to the Yugoslavian war, which generated internal and external displacement. Part II explains the EU response by setting a precedent for temporary protection status and describes the advantages and disadvantages of temporary protection status. Part III shows the modern picture of temporary protection status, including its benefits and drawbacks. Part IV illustrates the Syrian refugee crisis, and its similarities to the former

5. Balkans War: A Brief Guide, BBC: EUROPE (Mar. 18, 2016), https://www.bbc.com/news/world-europe-17632399.

6. See David Sopf, Temporary Protection in Europe After 1990: The "Right to Remain" of Genuine Convention Refugees, 6 WASH. U. J.L. \& POL'Y 109, 110-12 (2001).

7. Karoline Kerber, Temporary Protection in the European Union: A Chronology, 14 Geo. ImMIGR. L.J. 35, 35 (1999) (quoting Note on International Protection, UNHCR, 44th Sess., at I 25 , U.N. Doc. A/AC.96/815 (1993)).

8. See Helene Lambert, Temporary Refuge from War: Customary International Law and the Syrian Conflict, 66 INT'L \& COMP. L.Q. 723, 745 (2017).

9. See Kim Rygiel et al., The Syrian Refugee Crisis: The EU-Turkey 'Deal' and Temporary Protection, 16 GLOBAL SOC. POL'Y 315, 316 (2016).

10. Caldwell, supra note 1, at 1-2. 
Yugoslavian refugee crisis. Finally, Part V argues that just as temporary protection status was granted to Yugoslavian refugees, so too should it be granted to Syrian refugees today.

\section{THE YUgOSLAVIAN PRECEDENT}

The Federal People's Republic of Yugoslavia was established in 1946 and re-formed after the Axis invasion of Yugoslavia during World War II. ${ }^{11}$ The newly established Yugoslavia created six republics of Slavic States and was occupied by Albanians, Bosnian-Muslims, Croats, Serbs, and Slovenes. ${ }^{12}$ Initially, deep distrust stemmed from class deviations between Croat elites and the Serbian people ${ }^{13}$ followed by conflicts rooted in the religious transition of Bosnians to Islam. ${ }^{14}$ The conversion increased the social status and wealth of Bosnians because the Ottoman Empire rewarded individuals practicing Islam. $^{15}$ The growing resentment led to a lack of contact between the ethnic groups, which further festered feelings of oppression and frustration. ${ }^{16}$

A fleeting moment of tranquility was felt under the communist leadership of President Josip Broz Tito, ${ }^{17}$ who ascended to power in $1963 .{ }^{18}$ Tito's political actions were mainly focused on suppressing the tensions between the various ethnic groups: ${ }^{19}$ " $[\mathrm{h}] \mathrm{e}$ enacted a constitution, [formed] a strongly centralized state, and reduced private enterprise. ${ }^{20}$ However, progress was short lived, and tensions returned when economic problems arose $\mathrm{e}^{21}$ and the eight-member executive branch could not agree on a comprehensive solution. ${ }^{22}$

National groups began to pressure the separate republics to assert autonomy as a result of the continuous tension, which led to declarations of independence by Croatia and Slovenia in 1991 and eventually Bosnia. ${ }^{23}$ Slobodon Milošević, the president of the League of

\footnotetext{
11. Balkans War: A Brief Guide, supra note 5.

12. $I d$.

13. Caldwell, supra note 1, at 3-4.

14. See Lisa L. Schmandt, Comment, Peace with Justice: Is it Possible for the Former Yugoslavia?, 30 TEX. INT'L L. J. 335, 337 (1995).

15. Caldwell, supra note 1 , at 5 .

16. $I d$.

17. Balkans War: A Brief Guide, supra note 5.

18. Tito is Made President of Yugoslavia For Life, HIST. (last updated July 27, 2009), https://www.history.com/this-day-in-history/tito-is-made-president-for-life.

19. Balkans War: A Brief Guide, supra note 5.

20. Caldwell, supra note 1 , at 8 .

21. Id. at 8-9.

22. Id.

23. Balkans War: A Brief Guide, supra note 5.
} 
Communists in Serbia, met these declarations with hostility. ${ }^{24}$ Milošević rose to power because of his strong assertions that Serbians were being oppressed based on their religion and that anyone not fighting for the Serbian cause was the enemy. ${ }^{25} \mathrm{He}$ effectively relayed his message to the Serbian people, and his rhetoric received large amounts of support. ${ }^{26}$ The Serbian people were readily united under one leader that could "effectively fight their cause, [and] unite[ the Serbs throughout Yugoslavia."27

On May 2, 1991, the first shots were fired in Borovo Selo, Croatia, officially beginning the war. ${ }^{28}$ Homes were looted and burned to the ground, and violence quickly took the form of ethnic cleansing throughout Croatia. ${ }^{29}$ War atrocities consequently caused Croatia's Serb minority to declare a third of Croatia's territory as their own. ${ }^{30}$ For years, the one-sided fighting continued before Croatian authorities gained enough resources to equip their armed forces and assert dominance over their taken territory. ${ }^{31}$

A pivotal moment occurred in 1995: Croats went on the offensive and regained the majority of their territory, which resulted in thousands of Serbs fleeing back to Bosnia and Serbia. ${ }^{32}$ The war eventually spread to Bosnia and Herzegovina, where Bosnian villages and major cities were quickly seized. ${ }^{33}$ Within only a few days of mobilizing, Serbs controlled sixty percent of Bosnian territory. ${ }^{34}$ Croats also "attempt[ed] to assert dominance over large chunks of [Bosnian Territory]" and even participated in secret meetings with Serbia to devise a plan to divide Bosnia by region. ${ }^{35}$ "The conflict [quickly] turned into a bloody three-sided fight for territories, with civilians of all ethnicities becoming victims of horrendous crimes." ${ }^{36}$ Acts of genocide ${ }^{37}$

24. See Cervoni, supra note 3 , at $482-83$.

25. Caldwell, supra note 1 , at 9-10.

26. Id.

27. $I d$.

28. Id. at 11 .

29. Id. at 11-12.

30. The Conflicts, UNITED NATIONS: INT'L CRIM. TRIBUNAL FOR FORMER YugOSLAVIA, http:/www.icty.org/en/about/what-former-yugoslavia/conflicts (last visited Oct. 13, 2018).

31. Id.

32. Id.

33. Ulrike Davy, Refugees from Bosnia and Herzegovina: Are They Genuine?, 18 SUFFOLK TRANSNAT'L L. REV. 53, 55 (1995).

34. Id. at 56.

35. The Conflicts, supra note 30 .

36. Id.

37. See Brenton L. Saunders, Comment, The World's Forgotten Lesson: The Punishment of War Criminals in the Former Yugoslavia, \& TEMP.. INT'L \& COMP. L.J. 357, 357 (1994); The Conflicts, supra note 30. 
were committed all across Bosnian cities: Bosnian women were raped, brutal detention centers were constructed, and disturbing intimidation techniques were utilized-resulting in the death of thousands of Bosnian-Muslims. ${ }^{38}$

\section{A. The Refugee Crisis}

The violence and brutality occurring in the former Yugoslavia would soon lead to one of the largest European refugee crises. At the beginning of the war, Bosnia and Herzegovina was separated by three major ethnic groups: "forty-three percent Bosniak, thirty-one percent Serb, seventeen percent Croat, and nine percent other." ${ }^{39}$ These groups were originally intertwined throughout the region, but the war would separate them along ethnic lines. ${ }^{40}$ Ultimately, the war successfully dislocated 2.3 million Croats, Bosnians, and Serbs from their homes. ${ }^{41}$ This number includes external displacement (movement of refugees to non-Yugoslavian states) and internal displacement (movement of refugees within the former republics). ${ }^{42}$ For example, "ninety percent of the pre-war Bosnian-Serb population left the area now called the Federation [local government mainly controlled by Bosnians] and over ninety-five percent of the pre-war Bosnian-Croat and Muslim inhabitants fled what would become the Republika Srpska ("RS") [local government mainly controlled by Serbs] during this period." 43 By the end of the war, external and internal displacement only allowed "fortytwo percent of people [to] remain] in their home of origin." 44

The separation of populations along ethnic lines and the dislocation of ethnic groups were mainly consequences of ethnic cleansing campaigns. ${ }^{45}$ At the start of the war, these campaigns were justified because they were part of a "premediated [military] plan" to gain control over territory. ${ }^{46}$ However, it quickly became clear that these campaigns were developed to "purify" territories ${ }^{47}$ by "forcibly displacing [and]

38. The Conflicts, supra note 30.

39. Rosand, supra note 4, at 1098.

40. Id. at 1098-99.

41. Id. at 1092 .

42. See Mark R. von Sternberg, A Comparison of the Yugoslavian and Rwandan War Crime Tribunals: Universal Jurisdiction and the "Elementary Dictates of Humanity", 22 BROOK. J. INT'L L. 111, 121 (1996).

43. Rosand, supra note 4, at 1100.

44. Id.

45. Id. at 1092-93.

46. Id. at 1093.

47. Sopf, supra note 6 , at 110 . 
killing members [of certain religious] and opposing ethnic groups." 48 Refugees "were not the tragic by-product of a civil war; their expulsion was the whole point of the war." 49 They were displaced because of intimidation techniques ${ }^{50}$ and were threatened with further violence if they stayed. 51

A severe housing crisis also contributed to the displacement, as homes were destroyed and individuals were forced to move to metropolitan areas. ${ }^{52}$ Homes in urban cities were distributed for political gain ${ }^{53}$ and along ethnic lines, furthering the need for individuals to search for new temporary homes. ${ }^{54}$

\section{B. External Response}

The massive refugee crisis forced European States to search for answers within their current, inadequate system, leading to the creation of an altogether new system. ${ }^{55}$ Until the Yugoslavian crisis, the only refugee protections available were the 1951 Convention Relating to the Status of Refugees and the 1967 Protocol Relating to the Status of Refugees. ${ }^{56}$ The 1951 Convention protected the political refugees of World War II, ${ }^{57}$ who were not expected to return home, and who were typically given lasting citizenship in host countries. ${ }^{58}$ The host countries provided these refugees with safe havens and gradually integrated them into their country. ${ }^{59}$ The Convention required the following elements:

(1) the claimant left his country of origin, or a stateless person left his country of habitual residence; (2) there exists an actual risk of harm in the country of origin; and (3) the claimant must prove a well-founded fear of persecution. Other required elements relate to an explicit link between the claimant's fear of persecution and an internationally recognized human rights

48. Rosand, supra note 4 , at 1093 .

49. Caldwell, supra note 1 , at 14 (quoting LAURA SIBLER \& ALLEN LITTLE, YUGOSLAVIA: DEATH OF A NATION 244-45 (1995)).

50. Rosand, supra note 4, at 1099.

51. Caldwell, supra note 1 , at 14 .

52. Rosand, supra note 4, at 1100-01.

53. Id. at 1101 .

54. See id.

55. Sopf, supra note 6 , at 111.

56. Id. at 110

57. Id. at 110-11.

58. Id. at 110 .

59. Id. 
violation, as well as an objective failure of the State's duty to provide protection to its nationals. In addition, the risk of persecution must have a direct link to the claimants, race, religion, nationality, membership in particular social groups, or political opinions. ${ }^{60}$

However, the Yugoslavian refugee crisis presented an obstacle that could not be solved by the legal framework of the 1951 Convention. ${ }^{61}$ The 1951 Convention was created for the displacement of small groups of political refugees but was not adequately framed to handle the displacement of millions. ${ }^{62}$ Moreover, Member States could not agree on an interpretation or characterization of the war. ${ }^{63}$ In the early stages of the war, many Member States viewed the conflict as a "civil war" and were unwilling to classify the conflict as a genocide. ${ }^{64}$ Therefore, Member States were unwilling to provide refugee protection to persons escaping former Yugoslavia. ${ }^{65}$ This stance was justified by defining a "civil war" as a generalized form of violence, ${ }^{66}$ where the "generalized violence [is] not motivated by . . . race, religion, ethnic origin or political opinion." 67 Further stating, these persons were persecuted because of the "general situation in their country of origin" 68 and not because of their personal traits. ${ }^{69}$

Another obstacle was the sheer number of refugees which led to inadequacies in the Convention's framework. ${ }^{70}$ Great discrepancies in burden sharing among European States were revealed-which had not been previously visible when post-World War II protections had only been extended to a small number of political refugees. ${ }^{71}$

The strict position held by European States did not stop the need for protection for persons escaping the atrocities of the Yugoslavian War. ${ }^{72}$ To provide protection and to prevent large amounts of people from crossing international borders, the European Union adopted the

60. Id. at 122 .

61. Id. at $110-11$.

62. Id.

63. See id. at 111.

64. Id. at 111.

65. $I d$.

66. See PIRKKo Kourula, BRoAdening the EDGEs: REFUgeE DEFINITION AND INTERNATIONAL PROTECTION REVISITED 157-58 (1997).

67. Sopf, supra note 6 , at 123.

68. Id.

69. Id.

70. Id. at 110 .

71. Id. at 111 .

72. See id. 
"temporary protection status" legal framework for the first time. ${ }^{73}$ This status was formed under two premises: "the obligation of a State not to produce refugee outflows, and the right of people to return to their home country."74 Under this new framework, States were presented with an obligation to provide a minimum standard of care for their citizens, and if their citizens were displaced to another state, the citizens had the right to eventually return home. ${ }^{75}$ The "right to return" became a human right acknowledged by the European Union and was used to frame the discussion of temporary protection status. ${ }^{76}$ In other words, returning refugees to their home of origin became the main goal of this framework.

\section{TEMPORARY PROTECTION STATUS}

Temporary protection status combines two conflicting principles: state sovereignty and humanitarianism. ${ }^{77}$ These principles were the basis for the general legal concepts of the resolution when formalizing temporary protection status. ${ }^{78}$ The resolution was designed to be a flexible approach that allowed States to make decisions "based not only on the humanitarian needs of the affected persons but also on the situation in the Member States."79

In June of 1993, EU Member States passed a resolution in Copenhagen ("Copenhagen Resolution"), which stated an intention to grant temporary protection status to Yugoslavians that met certain conditions. ${ }^{80}$

The resolution ${ }^{81}$ not only specified who was to be admitted, but also suggested various principles that Member States should consider when

73. Id. at 112 .

74. Id.

75. $I d$.

76. Id.

77. Id. at 117. See generally GooDWIN-GILL \& MCADAM, supra note 4 (analyzing the framework of international refugee law).

78. See Kay Hailbronner, Comment, Temporary and Local Responses to Forced Migrations: A Comment, 35 VA. J. INT"L L. 81, 89 (1994).

79. $I d$. at $89-90$.

80. Id. at 86 .

81. The resolution states:

(1) Member States, in compliance with their national procedures and laws, will take suitable measures for the admittance, within the limits of the possibilities of each Member State, of particularly vulnerable persons from the former Yugoslavia in order to afford them temporary protection.

These arrangements are especially intended to apply to:

(a) persons from the former Yugoslavia who:

[i] have been held in a prisoner-of-war or internment camp and cannot 
accepting refugees. ${ }^{82}$ It suggested host countries provide resources so that refugees could have the opportunity to live in suitable environments ${ }^{83}$ and suggested providing refugees with special benefits, including health care and participation in local associations. ${ }^{84}$ The Member States believed that refugees were allowed these entitlements until the conditions in their home country were deemed "suitable for their return." 85

Prior to this formal resolution, only "a few Western European States like Switzerland, Austria, and Germany" allowed entry on a temporary basis for refugees. ${ }^{86}$ For example, Germany admitted 350,000 Bosnians in March of 1995 (post-resolution). ${ }^{87}$ Even though this resolution did not create a uniform standard, it did shift some of the burden to Member States that initially refused to allow entry to refugees. ${ }^{88}$ Having the European Union highlight its stance on providing greater protection to Yugoslavian refugees forced Member States into action. ${ }^{89}$ However,

otherwise be saved from a threat to life or limb;

[ii] are injured or seriously ill and for whom medical treatment cannot be obtained locally;

[iii] are under a direct threat to life or limb and whose protection cannot otherwise be secured;

[iv] have been subjected to sexual assault, provided that there is no suitable means for assisting them in safe areas situated as close as possible to their homes;

(b) persons from the former Yugoslavia who have come directly from combat zones within their borders and who cannot return to their homes because of the conflict and human rights abuses.

(2) Member States will endeavor to administer such arrangements on the basis of the overall objective that persons from the former Yugoslavia who are admitted to the Member States and given temporary protection are to return to an area in the former Yugoslavia in which they can live in safety as soon as the conditions in that area make it possible to do so in safety.

(3) Each Member State will make every effort to take the measures required to enable the persons concerned to stay on its territory temporarily within the framework of the general objective referred to in point 2 .

European Commission Press Release 548/93, Council Resolution on Certain Common Guidelines as Regards to the Admission of Particularly Vulnerable Groups of Distressed Persons From Former Yugoslavia (June 1993); Id. at 86-87.

82. Hailbronner, supra note 78, at 86-87.

83. Id. at 87.

84. Id. at $87-88$.

85. Id. at 87 .

86. Id. at 88 .

87. Kerber, supra note 7 , at 36 .

88. Hailbronner, supra note 78 , at 88 .

89. See id. 
there was still no requirement forcing states to allow entry to displaced individuals. ${ }^{90}$

\section{A. Possible Downfalls: Variation in the Interpretation of International Law}

Even though temporary protection status is premised on providing a minimum standard of care for all individuals, its application comes with potential downfalls. The Copenhagen Resolution provided European States with a considerable amount of leeway in determining who qualified for temporary protection status. ${ }^{91}$ European States considered a variety of factors when determining status. ${ }^{92}$ Some Member States only allowed entry to individuals from "designated areas." 93 Other Member States "favored only specific types of refugees, such as the wounded and sick, those who had been held as a prisoner-of-war or in an internment camp, deserters, or the elderly." "94 Additionally, disagreements on legal procedure caused variations in admission. ${ }^{95}$ The variety of distinctions set by States made it difficult for refugees to predict whether they would be granted temporary protection status from a European State. ${ }^{96}$ This was extremely problematic because many refugees were subject to possible ethnic cleansing or other forms of violence and fighting if they stayed in their country of origin. ${ }^{97}$

Additionally, granting refugees temporary protection status raised issues as to what rights the individuals should be afforded. ${ }^{98}$ All Member States allowed refugees to receive an education, but only up to the secondary school level. ${ }^{99}$ Some states allowed for automatic work authorization, while others required refugees to wait a certain amount of time prior to receiving work authorization. ${ }^{100}$ Additionally, States differed on allowances for family unification and on what social services should be provided. ${ }^{101}$ This brings forward serious questions regarding what rights should be granted to individuals only staying in a region

90. Sopf, supra note 6 , at 131 .

91. Kerber, supra note 7, at 36-37.

92. See $i d$. at $36-37$.

93. Id. at 37 .

94. Id.

95. Id. at 38 .

96. See id.

97. See generally Rosand, supra note 4 (discussing how ethnic cleansing caused mass displacement).

98. Kerber, supra note 7 , at 37 .

99. Id.

100. Id.

101. Id. 
temporarily. Should they be provided with the full rights given to States' citizens? Or are States comfortable with providing partial rights to refugees because they are only expected to temporarily reside in the State? The variation in rights also led to discrepancies in burden sharing: States known for providing greater benefits received more applications for temporary protection status and were burdened with a higher cost. ${ }^{102}$

The final issue is to where refugees would return: "whether return to other parts of the country [is] permissible, or whether return should . . . take[ place at the original and habitual residences of the returnees." 103 The Bosnian government specified the areas that refugees were allowed to return, largely separated among ethnic lines. ${ }^{104}$ International law does allow for alternative settlement options when the place of origin does not meet safety requirements, ${ }^{105}$ but when are these requirements met, and when are they breached? ${ }^{106}$ What happens when homes and cities are destroyed in a refugee's home country? Is it acceptable to force refugees to leave a host country to which they may have now grown accustomed?

The reality is many refugees will return to '“majority areas,' in which people do not return to their original homes but to the areas of their ethnic majority as designated by government." 107 The concept of temporary protection status was initially created to promote stability and peace in former Yugoslavian republics. ${ }^{108}$ However, as refugees returned to their origin countries and were forced into new homes, peace was not felt and tensions were simply masked by ethnic divisions. ${ }^{109}$

\section{B. The Possible Need for Temporary Protection Status}

"Temporary protection developed as a pragmatic answer to meet the protection needs of a group of refugees hitherto not covered by legal refugee instruments." 110 Despite the limited protections provided, temporary protection status serves as an immediate solution for a mass

102. Id. at 39 .

103. Sopf, supra note 6 , at 152.

104. Id. at $152-53$.

105. See Alexandra McGinley, The Aftermath of the NATO Bombing: Approaches for Addressing the Problem of Serbian Conscientious Objectors, 23 FORDHAM INT'L L.J. 1448, $1473(2000)$.

106. See Sopf, supra note 6, at 153.

107. Id. at 155-56.

108. See id. at 111-12.

109. See id. at 154.

110. Hailbronner, supra note 78 , at 94. 
group of refugees. ${ }^{111}$ Compared to asylum proceedings, temporary protection proceedings are quicker and are more open to modification. While flexibility may lead to predictability concerns, States may construct a process that best fits their existing legal system while ensuring their sovereignty. ${ }^{12}$ The system is tailored to the particular State which will hopefully lead to a speedier immigration process.

In being granted temporary protection status, refugees are provided with rights to begin rebuilding their lives such as working for an income, education, and more. ${ }^{13}$ These rights are extremely limited when compared to the rights of EU citizens but nonetheless may provide more opportunities than those provided in a refugee's home country.

\section{MODERN TEMPORARY PROTECTION STATUS}

Modern temporary protection status was created by the Amsterdam Treaty of 1999, which required the Council of the European Union to issue a directive setting the minimum standards for temporary protection status. ${ }^{114}$ This Directive was issued on July $20,2001,{ }^{115}$ and consisted of nine Chapters specifying how the European Union was to deal with a mass influx of displaced persons. ${ }^{116}$ The European Commission set a series of objectives that they hoped to reach with the Directive:

[T]o satisfy the requirements of the Amsterdam Treaty; to avoid an overloading of the national asylum systems in the event of a mass influx and the resulting negative impact on Member States and the persons involved; to afford immediate protection and a fair set of rights to displaced persons; to clarify the link between temporary protection and the Geneva Convention; to contribute to balancing the efforts made by Member States confronted with a mass influx of displaced persons through providing coordination facilities; and to achieve

\footnotetext{
111. See id.

112. See id at 98 .

113. See id. at 87 .

114. Council Directive 2001/55/EC, ๆ 5, 2001 O.J. (L 212) 12.

115. Scott Reynolds, Comment, European Council Directive 2001/55/EC: Towards a Common European Asylum System, 8 COLUM. J. EUR. L. 359, 359 (2002).

116. Id. at 360 .
} 
solidarity in the reception of displaced persons, both financially and in the physical act of reception. ${ }^{117}$

Regarding procedural requirements, the definition of a "mass influx of displaced persons" was not quantitatively or qualitatively defined by the Commission. ${ }^{118}$ However, it is generally understood to mean a "considerable numbers of persons arriving over an international border" 119 at "a rapid rate of arrival." ${ }^{20}$ Regardless, the meaning is still established by a majority vote of the Commission and is decided on a case-by-case basis dependent on the conflict taking place. ${ }^{121}$ If the Commission finds a mass influx of refugees in a State, then "the maximum time limit [for temporary protection status is two years] (. . . with the possibility of a one year extension)." ${ }^{122}$ Member States may also choose to exclude certain persons from protection if the persons have "committed crimes against humanity, war crimes, and the like, as well as serious non-political crimes and acts contrary to the principles of the United Nations." 123

The procedure for return requires that Member States fully disclose all relevant information regarding the refugees' status to the refugees, so they have a complete understanding of their present situation. ${ }^{124}$ The Directive prefers voluntary return but does allow Member States to take a variety of measures to enforce the return of persons, ${ }^{125}$ as long as they "consider any compelling humanitarian reasons that make[s] return impossible or unreasonable in specific cases." 126

Despite the general and approved standards set by the Directive, no Member States have implemented the Directive due to its underlying issues. ${ }^{127}$ There have been a few attempts to activate the status, but the

117. $I d$.

118. See Susan M. Akram \& Terry Rempel, Temporary Protection as an Instrument for Implementing the Right of Return for Palestinian Refugees, 22 B.U. INT'L L.J. I, 96 (2004).

119. Alice Edwards, Temporary Protection, Derogation and the 1951 Refugee Convention, 13 Melbourne J. INT'L L. 595, 603 (2012) (quoting U.N. High Comm'r Refugees, Protection and Cooperation in Mass Influx Situations, of 3, UN Doc EC/54/SC/CRP.11 (June 7, 2004)).

120. Id. (quoting U.N. High Comm'r Refugees, Protection and Cooperation in Mass Influx Situations, ๆ 3, UN Doc EC/54/SC/CRP.11 (June 7, 2004)).

121. See Reynolds, supra note 115 , at 360.

122. Id.

123. Id. at 361 .

124. See id.

125. Id. at $361-62$.

126. Id. at 362 .

127. Marco Notarbartolo di Sciara, Temporary Protection Directive, Dead Letter or Still Option for the Future? An Overview on the Reasons Behind its Lack of Implementation, 
attempts have been squashed for political and legal reasons. ${ }^{128}$ The Directive requires a complex legal evaluation because "it rests on [an] . . - ambiguous legal notion[": the phrase "mass influx of displaced persons" is impossible to define given the Directive's wide scope. ${ }^{129}$ Member States have differing perspectives on the meaning of this phrase because their definitions are politically motivated. ${ }^{130}$ These legal and political disagreements are amplified when combined with the requirement of a two-thirds majority approval. ${ }^{131}$

States also worry that the short duration of temporary protection status makes activation not worthwhile. ${ }^{132}$ The Member States fear that by activating temporary aid they will attract displaced persons to choose Europe over other geographic areas. ${ }^{133}$ They are concerned that this will only worsen the current refugee crises before a concrete solution is established, ${ }^{134}$ therefore, only encouraging refugees to remain rather than return to their home country. ${ }^{135}$ Additionally, many refugees will have forged ties to the community, which will stir a debate as to whether these individuals should receive lawful permanent status. ${ }^{136}$

\section{THE SYRIAN REFUGEE CRISIS}

The possible need for temporary protection status is seen in the aftermath of the Syrian Civil War. As of March 2019, Syria's Civil War has generated one of the world's worst humanitarian crises: 5.7 million Syrians have left the country and 6.1 million Syrians have been displaced internally. ${ }^{137}$ In 2011, due to the Arab Spring, Syrians prodemocracy activists started to gain hope that a progressive movement

EUROJUS.IT REVISITA (Feb. 12, 2015), http://rivista.eurojus.it/temporary-protectiondirective-dead-letter-or-still-option-for-the-future-an-overview-on-the-reasons-behind-itslack-of-implementation/?print=pdf.

128. Id.

129. Id.

130. See id.

131. Id.

132. Id.

133. Id.

134. Id.

135. See Claire Bergeron, Temporary Protected Status After 25 Years: Addressing the Challenge of Long-Term "Temporary" Residents and Strengthening a Centerpiece of US Humanitarian Protection, 2 J. MigRaTION \& HuM. SECURITY 22, 29 (2014).

136. See Temporary Protected Status: Overview and Current Issues, EVERYCRSREPORT (last updated Mar. 29, 2019), https:/www.everycrsreport.com/reports/RS20844.html.

137. Syrian Civil War Fast Facts, CNN (last updated Oct. 11, 2019), https://www.cnn.com/2013/08/27/world/meast/syria-civil-war-fast-facts/index.html. 
was achievable. ${ }^{138}$ The Syrian government quashed peaceful prodemocracy protests in Syria by killing and imprisoning demonstrators. ${ }^{139}$ As a result of this violence, in July of 2011, "defectors from the military announced the formation of the Free Syrian Army." 140 Syria's Civil War began as the Free Syrian Army worked to overthrow the current government. ${ }^{14 i}$ Over the next couple of years, this conflict spurned great instability in Syria, which allowed jihadist groups to take over significant sections of the country. ${ }^{142}$ "The Syrian Civil War thereafter became a multi-pronged conflict, with numerous foreign and local entities interested in the outcome, including the United States, certain EU countries, the Assad regime, Russia, Iran, Turkey, and Islamic extremists." 143

The conflict propagated a massive refugee crisis whereby "five million refugees ... fled Syria ... [and most entered into] neighboring countries," and approximately seven million refugees were "displaced within Syria."144 In response, the Turkish government enacted temporary protection laws to safeguard Syrians escaping violence and armed conflict. ${ }^{145}$

Article 91 of the 2013 Law specifies:

(1) Temporary protection may be provided for foreigners who have been forced to leave their country, cannot return to the country that they have left, and have arrived at or crossed the borders of Turkey in a mass influx situation seeking immediate and temporary protection. ${ }^{146}$

Article 7 of Regulation No 29153 (2014) further explains:

138. Syria's Civil War Explained from the Beginning, ALJAZEERA: MmDLE EAST (Apr. 14, 2018), https://www.aljazeera.com/news/2016/05/syria-civil-war-explained160505084119966.html.

139. $I d$.

140. Id.

141. Id.

142. Justin Huynh, Note, Tales of the Boat People: Comparing Refugee Resettlement in the Vietnamese and Syrian Refugee Crises, 48 COLUM. HUM. RTS. L. REv. 198, 213 (2016).

143. Id. at 213-14.

144. Lambert, supra note 8, at 735.

145. See generally Meltem Ineli-Ciger, Protecting Syrians In Turkey: A Legal Analysis, 29 INT'L J. REFUGEE L. 555 (2017) (describing the legal protections Turkey has set in place as a result of the Syrian refugee crises).

146. Lambert, supra note 8, at 737 (quoting Law No 6458, Official Gazette, No 28615 (11 April 2013) http://www.resmigazete.gov.tr/eskiler/2013/04/20130411-2.htm). 
[T]hat beneficiaries of temporary protection may be anyone 'to whom international protection status determination procedures do not apply'. Today, persons benefitting from temporary protection include all Syrian nationals, Palestinian refugees, and stateless persons living in Syria. ${ }^{147}$

Turkey has presented the Syrian people with an open-door policy that encompasses the standards set out in the 2011 Directive. ${ }^{148}$ The Turkish government has determined that the refugee crisis in Syria fits the definition of a "mass influx of displaced persons" and that the State has a duty to protect the refugees. ${ }^{149}$ As a result, Turkey is now hosting over three million Syrian refugees, ${ }^{150}$ more than double the number of refugees accepted by Lebanon, who hosts the second highest number of Syrian refugees. ${ }^{151}$ In contrast, the rest of Europe has "only extended protection to . . 217,000 Syrian refugees." 152

\section{Proposed IMPLEMENTAtion by EuRopean MEMber States}

Despite the legal and political flaws of the 2011 Directive, Turkey has continued to provide temporary protection status to Syrian refugees facing displacement. ${ }^{153}$ However, European Member States have refused to implement or even consider temporary protection status as a solution to the current crisis. ${ }^{154}$ Procedurally, it is difficult to understand why this protection has not been granted to displaced individuals. The 2011 Directive set broad standards and granted large amounts of discretion to Member States. ${ }^{155}$ The Directive's standards are likely already met due to its broad scope: "[i]t is difficult to deny the existence of a 'mass influx of displaced persons from third countries', as the current arrivals constitute an inflow of unprecedented proportion made almost

147. Id. (quoting Regulation (by-law') No 29153 on Temporary Protection-the Regulation art. 7 entered into force on 22 October 2014).

148. Ineli-Ciger, supra note 145 , at 557.

149. See id.

150. Id. at 577 .

15I. Major Yvonne S. Brakel et. al., 50 Years Was Too Long to Wait: The Syrian Refugee Crisis Has Highlighted the Need for a Second Optional Protocol to the 1951 Convention Relating to the Status of Refugees, 40 U. ARK. LITTLE ROCK. L. REV. 51, 60 (2017).

152. E. Tendayi Achiume, Syria, Cost-Sharing, and the Responsibility to Protect Refugees, 100 MINN. L. REV. 687, 689 (2015).

153. See Ineli-Ciger, supra note 145 , at 557.

154. See Notarbartolo di Sciara, supra note 127.

155. See id. at 123. 
exclusively of persons seeking international protection."156 The number of externally and internally displaced Syrian refugees exceed the number of Yugoslavian refugees by almost ten million individuals. ${ }^{157}$ Therefore, the number of refugees does not appear to be a valid reason for refusing to provide protection.

The overbroad legal framework may not be providing sufficient guidelines for States. One solution is to provide States with a structured international legal regime, narrower in scope, that better outlines determination procedures, the rights granted to refugees, and procedures for return. Stricter guidelines might pressure States to at least consider granting this status. A newly narrowed scope and carefully detailed status parameters, the European Union may actually consider its application.

In today's political climate, temporary protection status would be difficult to implement because States value their sovereignty, and the European Union has been reluctant to aggressively interfere within a State's border. ${ }^{158}$ Beginning in 2015, Europe's close neighbor, Russia, aligned itself with Assad's regime in Syria and provided considerable amounts of foreign backing to the Syrian government. ${ }^{159}$ Arranging protection to displaced persons who oppose the current Syrian regime could create detrimental political consequences to European Member States with close ties to Russia. States have historically prioritized the needs of their citizens before the needs of others. ${ }^{160}$ However, Russia was a close ally of Serbia during the Yugoslavian War and continues to have a close relationship. ${ }^{161}$ This relationship did not prevent European Member States from equipping a significant number of Bosnian-Muslim and Croat refugees with temporary protection status during the Yugoslavian War. ${ }^{162}$ During this period, States seemed to recognize that the severe violations of human rights constructed a duty of protection that exceeded the political arena. It is difficult to understand how this same duty is inapplicable within the context of Syrian refugees, who are facing conflicts similar to those faced by many Bosnian-Muslims and Croats but yet are not receiving equal treatment by the international community.

156. Id. at 127 .

157. See Rosand, supra note 4, at 1092; see Syrian Civil War Fast Facts, supra note 137.

158. See Notarbartolo di Sciara, supra note 127.

159. Syria's Civil War Explained from the Beginning, supra note 138.

160. See ERIC A. HeINZE, Global VIOLENCE: ETHICAL AND Political Issues 5 (2016).

161. See generally Léo-Paul Jacob, Keys to Understanding Russia's Relationship with Serbia, NAOC (Dec. 1, 2017), http://natoassociation.ca/keys-to-understanding-russiasrelationship-with-serbia/ (discussing Serbia's long relationship with Russia).

162. See Rosand, supra note 4 , at 1092 
Other underlying issues may be preventing European Member States from granting this protection. They may believe that this protection should only be provided to States within Europe. There may be a fear that once these individuals enter Europe, they will have no incentive to go back to their home country, though this same fear is not recognized with European refugees. However, the Directive does not require that refugees must arrive from a European state. ${ }^{163}$

Underlying religious animosity and a misplaced fear of terrorism may also be a deterrent. Yet, a majority of refugees during the Yugoslavian crisis were Muslims-the main religion in Syria. ${ }^{164}$ Arguably, a fear of terrorism did not exist in the Yugoslav era, or if it did, it was not as prevalent. A fear of terrorism must be taken in context with the atrocities faced by Syrian refugees. Currently, these fears are allowed to fester under the flexibility provided to States; however, a strict legal framework may force states to deal with the real and prevalent problem of displacement and shift away from these concerns.

\section{CONCLUSION}

The current Syrian refugee crisis requires the use of the 2001 Directive as a formal solution to displacement and necessitates strong political support from the EU Member States. Historically, there was support for providing temporary protection status to Bosnian refugees; however, this support appears to have vanished with the current refugee crisis. This support is nonexistent despite the drastic similarities between both conflicts and the similarities between the groups of refugees. This lack of support indicates a drastic change in the way Member States are presently analyzing humanitarian crises and viewing the resulting displaced persons.

Disregarding the current conflict and the resulting refugee influx, goes directly against the objectives stated by the 2001 Directive. The European Union should look to its legal precedent. Temporary protection status should be granted to Syrian refugees because it offers a recourse for displaced persons that would not be covered by traditional legal protections, produces quicker results, and grants refugees with basic rights human rights not currently available in their home country. Despite the imperfections that underlie temporary protection status proceedings, it is still a recourse that needs to be seriously considered by the European Union and its Member States.

163. See European Commission Press Release 548/93, supra note 81.

164. Syrian Culture, CULTURAL ATLAS, https:/culturalatlas.sbs.com.au/syrian-culture/ syrian-culture-religion (last visited Nov. 11, 2019). 